\title{
Performance Analysis on Series and Parallel Circuit Configurations of a Four- Cell Thermoelectric Generator Module Design
}

Amirul Abdul Rashid, Nur Aqilah Mat Som, Gilbert Jugi Jimmy, Muhammad Hadrami Hamdan*

School of Mechanical Engineering, College of Engineering, Universiti Teknologi MARA, Shah Alam 40450 Selangor, Malaysia.

*corresponding author: hadramihamdan@gmail.com

\section{ABSTRACT}

This study presents a technique in recovering energy from low-grade waste heat of a Proton Exchange Membrane Fuel Cell (PEMFC). The goal is to study the functionality and performance using a multiple cell thermoelectric generator (TEG) module. The test bench consisted of a heating element, a test section, and a cooling section. The heating element supplied hot stream temperatures of $53^{\circ} \mathrm{C}$ and $58^{\circ} \mathrm{C}$ that represented the waste heat from an actual PEMFC stack. The module comprised of four TEG cells with heat pipes coupled with a heat sink system. The main variables were the TEG cooling modes of natural convection $(0 \mathrm{~m} / \mathrm{s})$ and forced convection (at $5 \mathrm{~m} / \mathrm{s}$ and 10 $\mathrm{m} / \mathrm{s}$ ), and the series and parallel circuit configurations of the module. At $58^{\circ} \mathrm{C}$ waste heat temperature, forced convection cooling at $10 \mathrm{~m} / \mathrm{s}$ gave the highest voltage and power output of $140 \mathrm{mV}$ and $1960 \mu \mathrm{W}$. The output of the series circuit was $168 \%$ higher than the parallel circuit. This initial simple TEG module design has shown that it has a good prospect to compensate for the ultra-low waste heat temperature of a PEMFC. Future designs of the modules need to identify a more optimized approach to improve the outputs and contribute to the long-term sustainability of PEMFC systems.

Keywords: fuel cells, thermoelectric generator, waste heat recovery

\section{Nomenclature}

$\begin{array}{ll}\Delta T_{T E G} & \text { temperature difference of the TEG surfaces }\left({ }^{\circ} \mathrm{C}\right) \\ R_{M P P} & \text { maximum power point internal thermal resistance of the TEG }(\Omega) \\ I_{S C} & \text { short circuit current }(\mathrm{mA}) \\ I_{T E G} & \text { current output of TEG }(\mathrm{mA}) \\ P_{T E G} & \text { power output of TEG }(\mathrm{W}) \\ R_{T E G} & \text { internal thermal resistance of the TEG }(\Omega) \\ V_{T E G} & \text { voltage of TEG }(\mathrm{mV}) \\ T_{h o t} & \text { waste heat temperature of PEMFC }\left({ }^{\circ} \mathrm{C}\right)\end{array}$

\section{Abbreviations}

$\begin{array}{ll}\text { PEMFC } & \text { proton exchange membrane fuel cell } \\ \text { MPP } & \text { maximum power point }(\mathrm{W}) \\ \text { WHT } & \text { waste heat temperature } \\ \text { WHR } & \text { waste heat recovery } \\ \text { FCV } & \text { fuel cell vehicle } \\ \text { USB } & \text { universal serial bus } \\ \text { DC } & \text { direct current } \\ \text { OCV } & \text { open circuit voltage (V) }\end{array}$

\subsection{INTRODUCTION}

Rising energy costs, environmental pollution, and global warming have shifted our focus towards energyefficient systems. A hydrogen fuel cell is a promising option for generating clean energy, especially in the transportation sector [1]. It can significantly improve air quality, health, and climate change by producing low greenhouse gas emissions [2]. The fuel cell utilizes hydrogen compound and oxygen as reactants to convert chemical energy by an electrochemical process. The reaction then produces electricity, water and heat. The 
amount of energy created by a fuel cell relies on several elements, involving the type of fuel cell and its size, operating temperature, and the pressure of the gases introduced into the cell [3]. Comparing all kinds of hydrogen fuel cells, the Proton Exchange Membrane Fuel Cell (PEMFC) is a viable technology for future vehicles. It operates at low temperature, enabling it to produce high power density and a quick start-up process.

Since the conversion process of the fuel cell is irreversible, a significant percentage of energy is wasted [4]. The amount of waste heat produced is approximately the same with its electric power, restricting its applied energy efficiency from 40 to 50\% [5-6]. This means that when a PEMFC generates $1 \mathrm{~kW}$ of electricity, the fuel cell concurrently produces thermal power at $1 \mathrm{~kW}$. The waste heat is dissipated out of the stack through its active coolant and through passive convection across its surfaces [7], where active cooling normally contributes $80 \%$ of the thermal dissipation to prevent the stack from overheating [8].

Waste heat recovery (WHR) is an important component in the sustainability agenda. However, technologies for effective low grade WHR is still undergoing intensive development, where a notable approach for hydrogen preheating has successfully proven to enhance the outputs of the PEMFC with higher energy utilization [9]. Thermoelectric generators (TEG) is a practical technology to convert low-grade waste heat into useful electrical energy. The produced power is then fed back into the system as an additional energy source, improving the economic value to the power system. For PEMFC, this potentially translates into huge savings in hydrogen fuel utilization and allows a faster acceptance of the technology as a clean energy producer.

A TEG is a semiconductor device governed by the Seebeck effect. Temperature difference along the junction of p-type and n-type thermoelements between the hot and cold sides of the TEG cell would lead to heat transfer across the thermoelements. Excitation of free electrons in the n-type terminal when heat flows through the semiconductor and its movement towards the p-type terminal leads to the generation of electricity. When there is a significant temperature difference between the two sides of the TEG, the electrical generation is greater. The thermoelectric effect is also observed for low-grade waste heat, which makes it suitable for WHR of a PEMFC [10].

The application of TEG for WHR has been explored in a variety of thermal energy systems, including fuel cells [11], gasoline engine exhaust [12], hybrid photovoltaic systems [13], and others. It has been demonstrated that integrating TEG results into increased energy efficiency. Guo et al. [14] proved that combining PEMFC with TEG results in about $21 \%$ higher maximum power density. Makki et al. [15] theoretically investigated an integrated hybrid system of a TEG with heat pipe-based photovoltaic. The hybrid system improved the efficiency of a conventional PV panel system from $8.6 \%$ to $10.7 \%$ with respect to $1 \mathrm{~m} / \mathrm{s}$ wind speed. In addition, intensive efforts by researchers in optimizing the heat transfer rates have been conducted to maximize energy recovery efficiency such as combining heat pipes and heat sinks for rapid cooling of the TEG and creating a higher heat transfer rate across the TEG cells [16].

Studies on the application of TEG modules for PEMFC waste heat recovery are growing. By experimenting with thermoelectric coolers, Hasani and Rahbar [17] demonstrated one viable alternative for WHR from a PEMFC. They used forced convection heat transfer over the heat sink to increase the power produced. Gao et al. [18-20] proposed a high-temperature PEMFC WHR system that utilizes TEG cells at the heat exchanger, where it is proven that varying the electrical connection types influences the subsystem power output. Chen et al. [21] tested the effect of multiple TEG modules in series circuit under different flow patterns and heating temperatures, and concluded that the power output of a TEG module cannot simply be predicted by summing up the power outputs of each TEG module in series. Further research was conducted by numerically comparing a single and dual TEG setup in series configuration, where approximately $43 \%$ of power improvement was obtained [22].

An integrated system of compressed air energy storage, PEMFC and TEG by Khanmohammadi et al. [23] resulted in an efficiency increase up to $31.85 \%$. Parise and Jones [24] presented a fuel cell thermal management model by considering the effects of internal cooling via thermoelectric modules. Sulaiman et al. [25-26] tested a TEG module with heat pipe and heat sink to recover ultra-low temperature waste heat from a $2 \mathrm{~kW}$ PEM fuel cell vehicle (FCV) where the highest registered power was $218 \mu \mathrm{W}$ for the single cell setup. B. Singh et al. [27] also experimented a similar single TEG module design with additional inlet swirl nozzle that produced the maximum power of $3056 \mu \mathrm{W}$. Mohamed et al. [28] applied numerical modelling to predict the outputs of a single cell TEG module designed for FCV waste heat recovery for different power train configurations.

Recovering low grade waste heat is a difficult research field. The literature study indicated that the fluid temperatures, heating and cooling system designs, as well as TEG electrical setup are important factors in achieving high power outputs from TEG WHR module. Previous studies also revealed the importance of integrated heat pipe and heat sink system to the TEG module for greater performance. This manuscript experimentally analyses the performance of a 4-cell TEG module with an integrated multiple heat pipes and heat sinks in the WHR system. The analytical domain is on recovering waste heat from a $2 \mathrm{~kW} \mathrm{FCV} \mathrm{with} \mathrm{reference}$ waste heat temperatures of $53^{\circ} \mathrm{C}$ and $58^{\circ} \mathrm{C}$ with varied cooling modes accounting the motion of the FCV. The main contribution is the determination of power output characteristics from parallel and series TEG circuit configuration that has not been critically compared before in mainstream literature. The outputs and details of this work may lead to future enhancements on TEG module designs for FCV WHR systems. 


\subsection{METHODOLOGY}

\subsection{Test bench and TEG module design}

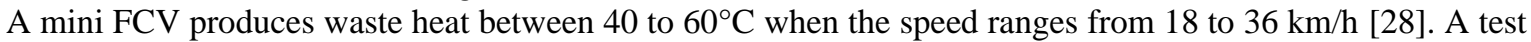
bench was developed according to these reference parameters for the hot stream and cold stream sides (as in Fig.1 and 2). The waste heat stream from the fuel cell stack was artificially provided by a heat gun. For this initial study, the applied hot stream temperatures were $53^{\circ} \mathrm{C}$ and $58^{\circ} \mathrm{C}$ that represented the waste heat stream from a PEMFC at $1910 \mathrm{~W}$ and $2038 \mathrm{~W}$, respectively. The cooling section comprised of an enclosure with a $12 \mathrm{~V}$ blower fan to provide the cooling air stream relative to the simulated FCV speed, between 5 to $10 \mathrm{~m} / \mathrm{s}$ at ambient temperature. The cooling fan was powered by a DC power supply to vary its speed.

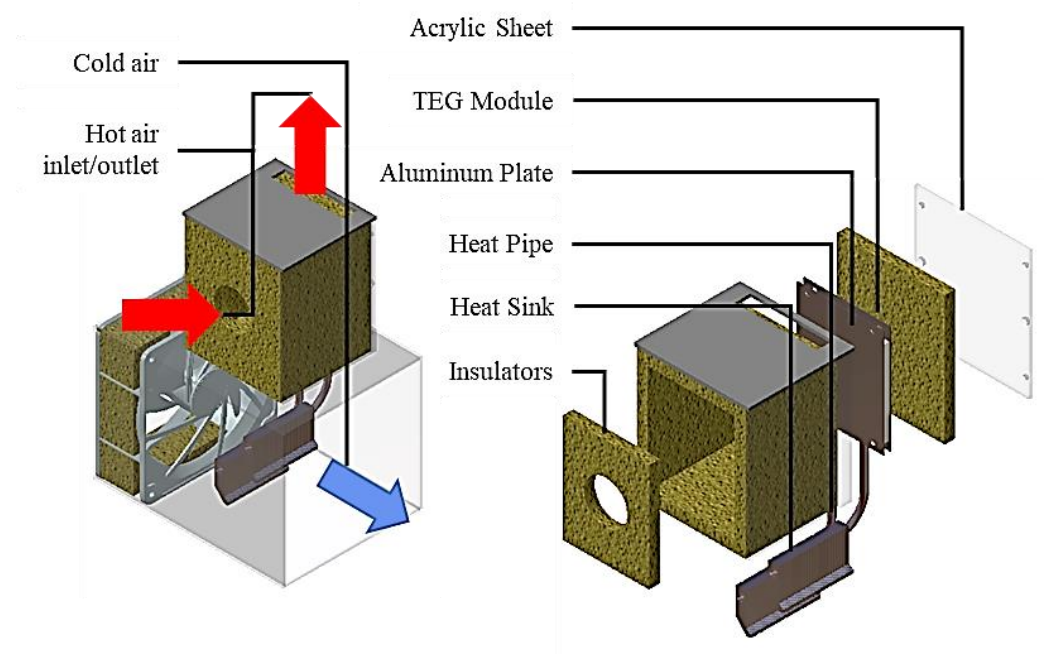

(a)

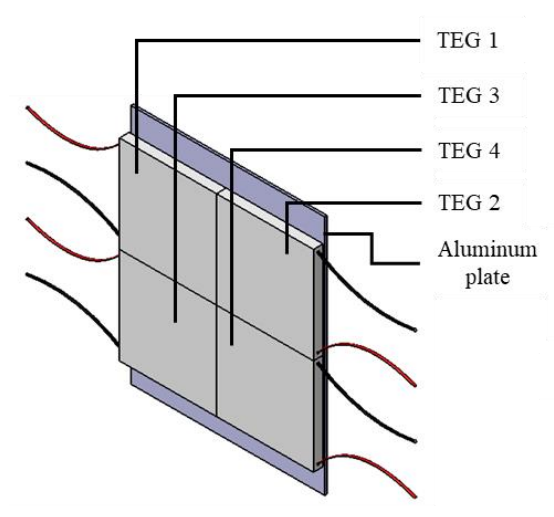

(c) (b)

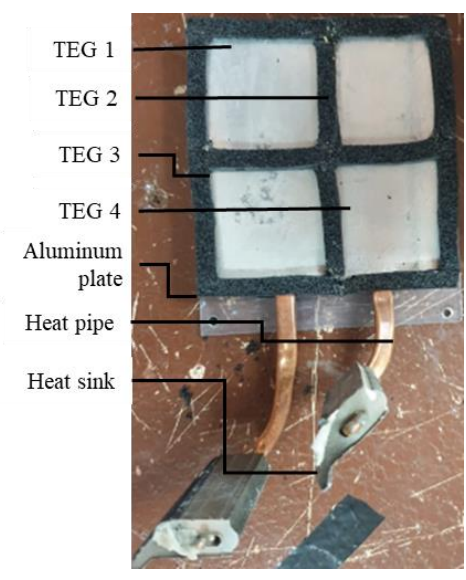

(d)

Figure 1: Design of the test bench and module - (a) Test bench assembly, (b) test bench exploded view, (c) TEG module assembly, and (d) actual TEG module

The TEG module was located at the heating section directly facing the hot gun. The TEG cells was arranged in parallel with airflow from the cooling fan to enhance heat absorption. The hot test section area was insulated to minimize heat loss to the surrounding. To avoid the hot air temperature from influencing the TEG cold side temperature, the top wall of the hot test section was partially opened for direct air outflow. For the electrical circuit connection of the TEG cell, series and parallel connections were applied to the module, and the circuit configuration is shown in Fig. 3.

The TEG module consisted of four TEG cells, each with two TEG cells paired with a heat pipe (further illustrated in Fig. 1d). Aluminium plates were attached to the hot side of the TEG to balance the heat and temperature distribution between the cells. At the cold side, each heat pipe was directly attached to the cell surfaces and the heat pipes were individually connected to a heat sink that was exposed to the cold air stream from the blower fan. Silicone thermal paste was used between the aluminium plate and the TEG surfaces. Thus, the cooling 
heat transfer motion started from the conduction through TEG semiconductor, aluminium plate, heat pipe, aluminium fins and the convection between the fins and cold stream ( 5 and $10 \mathrm{~m} / \mathrm{s})$.

Six k-type thermocouples were used to measure the temperature readings. The thermocouples were attached to the TEG surfaces and cooling device surfaces (refer Fig. 2), and connected to the GRAPHTEC midi LOGGER GL200A for data recording. Using the USB connector, the data logger was connected to a computer. The GL220_820APS software was installed for controlling and monitoring the data collection. To find the TEG's voltage-current characteristics, the cell's electrical output was measured using a DC Electronic Loader with the load resistance reduced from 400 to $0.5 \Omega$. The purpose is to obtain the output profile trendline as different operating conditions result in different polarization curves. The current and voltage of the TEG cell changes corresponding to the changes in load resistance. Table 1 lists the specifications of the devices and instrumentations used in this work.

Table 1: Specification of components and instrumentations

\begin{tabular}{|c|c|}
\hline Parameter & Description \\
\hline \multicolumn{2}{|l|}{ TEG } \\
\hline Material & Bismuth Telluride \\
\hline Operating Temperature & Max. $200^{\circ} \mathrm{C}$ \\
\hline Thermal Conductivity & $15-16 \times 10^{-3} \mathrm{~W} / \mathrm{m} .{ }^{\circ} \mathrm{C}$ \\
\hline Weight/ Dimension ( $\mathrm{L}$ x W x H) & $30 \mathrm{~g} / 40 \times 40 \times 4 \mathrm{~mm}$ \\
\hline No. of Thermo Element & 127 \\
\hline \multicolumn{2}{|l|}{ K-type Thermocouple } \\
\hline $\begin{array}{l}\text { Type / Temperature Range } \\
\text { (Conductor Material) / Conductor Size }\end{array}$ & $\begin{array}{r}\text { Insulated } / 0 \sim 600^{\circ} \mathrm{C} \\
\text { (Nickel Chrome/Nickel Aluminium) } / 0.4 \mathrm{~mm}^{2}\end{array}$ \\
\hline \multicolumn{2}{|l|}{ Acrylic Plate } \\
\hline Thickness & $3 \mathrm{~mm}$ \\
\hline Thermal Conductivity & $0.2 \mathrm{~W} / \mathrm{m} . \mathrm{K}$ \\
\hline \multicolumn{2}{|l|}{ Heat Pipe } \\
\hline Manufacturer & Sunyo Industry Co., Ltd. \\
\hline Material/ Working Fluid & Copper CU1020 / Deionized Water \\
\hline Allowable Operating Temperature & -50 to $200^{\circ} \mathrm{C}$ \\
\hline Thermal Conductivity / Max Heat Capacity & $400 \mathrm{~W} / \mathrm{m} . \mathrm{K} / 5-600 \mathrm{~W}$ per single pipe \\
\hline \multicolumn{2}{|l|}{ Heat Sink } \\
\hline Number of Fins & 55 \\
\hline Thermal Resistance/ (Thermal Conductivity) & $0.286 \mathrm{C} / \mathrm{W} /(400 \mathrm{~W} / \mathrm{m} . \mathrm{K})$ \\
\hline Fin Dimension ( $\mathrm{L} x \mathrm{H}$ x T) & $0.015 \times 0.012 \times 0.0001 \mathrm{~m}$ \\
\hline \multicolumn{2}{|l|}{ Data Logger } \\
\hline Type & GRAPHTEC midi LOGGER GL220A \\
\hline No. of Channel & (1) \\
\hline \multicolumn{2}{|l|}{ Heat Gun } \\
\hline Type / Temperature & Steinel $\mathrm{Hg} 3000$ sle $/ 50-650^{\circ} \mathrm{C}$ \\
\hline Power Input & $2000 \mathrm{~W}$ \\
\hline \multicolumn{2}{|l|}{ Electronic Load } \\
\hline Model & BK PRECISION 8540 150W DC Electronic Load \\
\hline Operation Range & 0-60 VDC, $1 \mathrm{~mA}-30 \mathrm{~A}$ \\
\hline \multicolumn{2}{|l|}{ DC Fan } \\
\hline Model / Airflow & Delta Electronics DC Brushless Fans / 252.85 CFM \\
\hline Size $(H \times D \times W)$ & $120 \times 38 \times 120 \mathrm{~mm}$ \\
\hline Voltage & $12 \mathrm{DC}$ \\
\hline
\end{tabular}

Table 2: Specifications of the experiment parameters

\begin{tabular}{lr}
\hline Parameters & \multicolumn{2}{c}{ Details } \\
\hline Electrical Connection & Series, Parallel \\
WHT $\left({ }^{\circ} \mathrm{C}\right)$ & 53,58 \\
Cooling Mode $(\mathrm{m} / \mathrm{s})$ & $0,5,10$ \\
Load Resistance $(\Omega)$ & $0-400$ \\
\hline
\end{tabular}

Table 2 specifies the experimental parameters. The tests were initiated by running the hot gun and cooling fan at its designated conditions for approximately 5 minutes to obtain steady-state temperatures at the TEG surface. Then, the resistances were varied, and the voltage and current were recorded. From the I-V curve, the power output of the TEG at a specific circuit resistance is

$$
P_{T E G}=I_{T E G} \times V_{T E G}
$$

The whole process was repeated for different variables (waste heat temperatures, circuit configuration, cooling modes). 


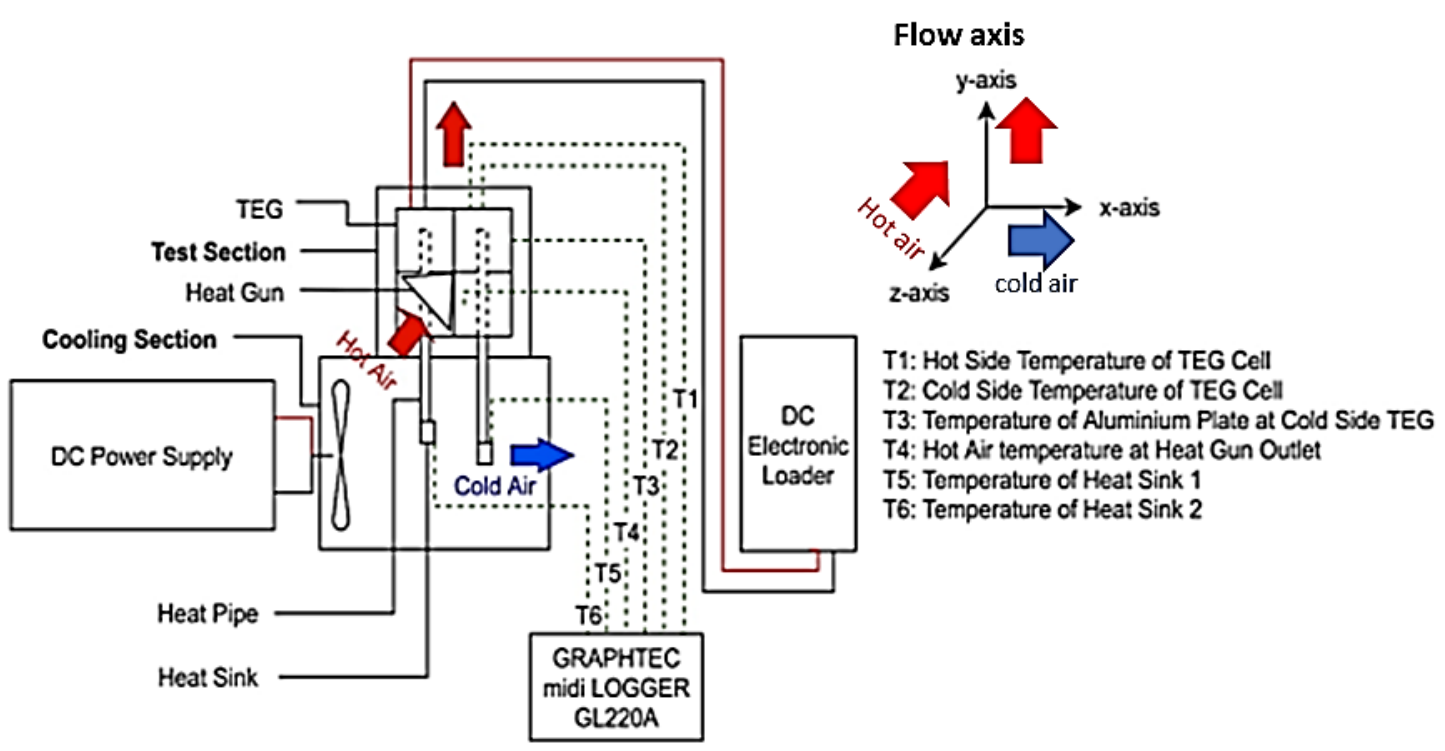

(a)

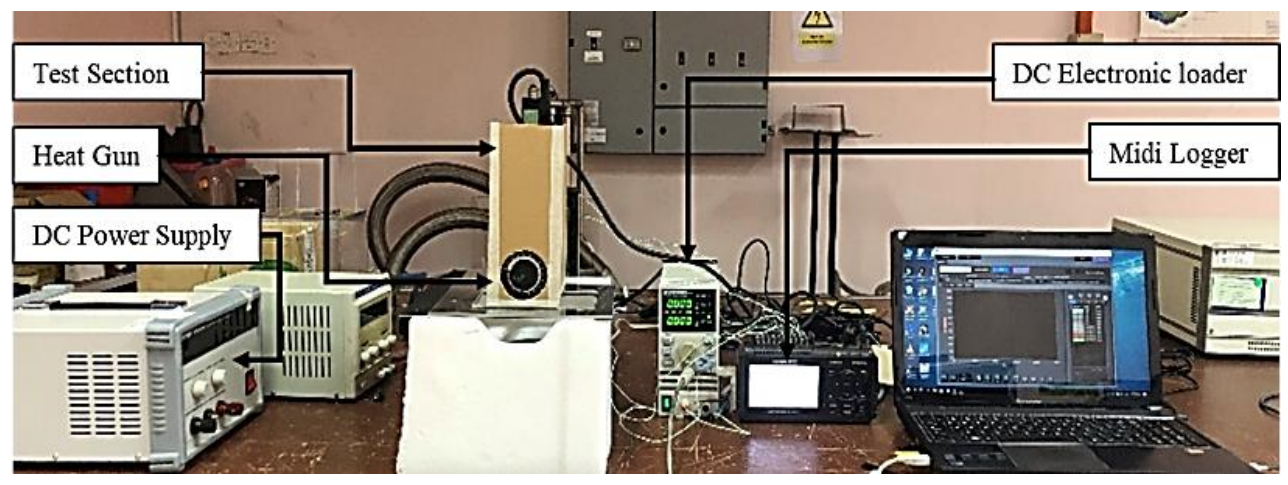

(b)

Figure 2: Test bench setup (a) schematic diagram, (b) actual setup

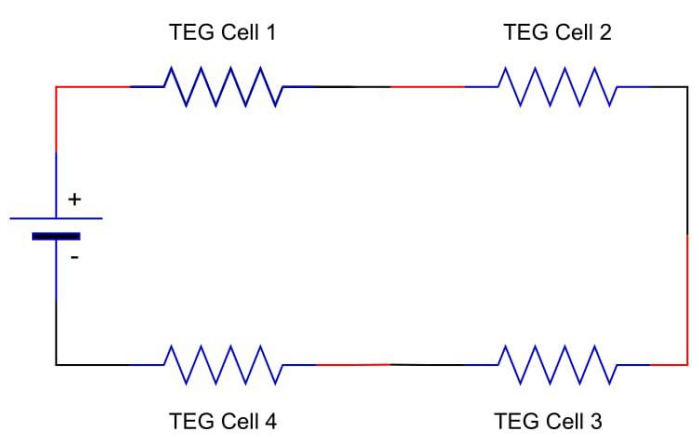

(a)

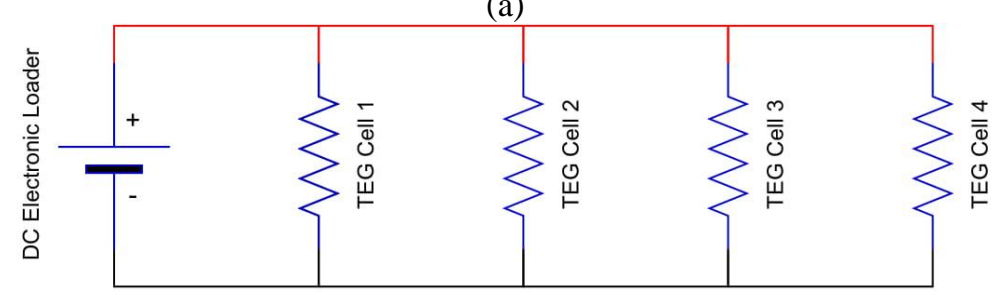

(b)

Figure 3: Electrical connection of TEG (a) series, (b) parallel 


\subsection{RESULTS AND DISCUSSION}

The experiment was designed to obtain the performance of a multi-cell thermoelectric generator with variations of waste heat temperatures and cooling air velocities. The main discussions are on the TEG surface temperatures and the electrical outputs based on the I-V and P-V profiles, as well as evaluating the maximum power and resistance values.
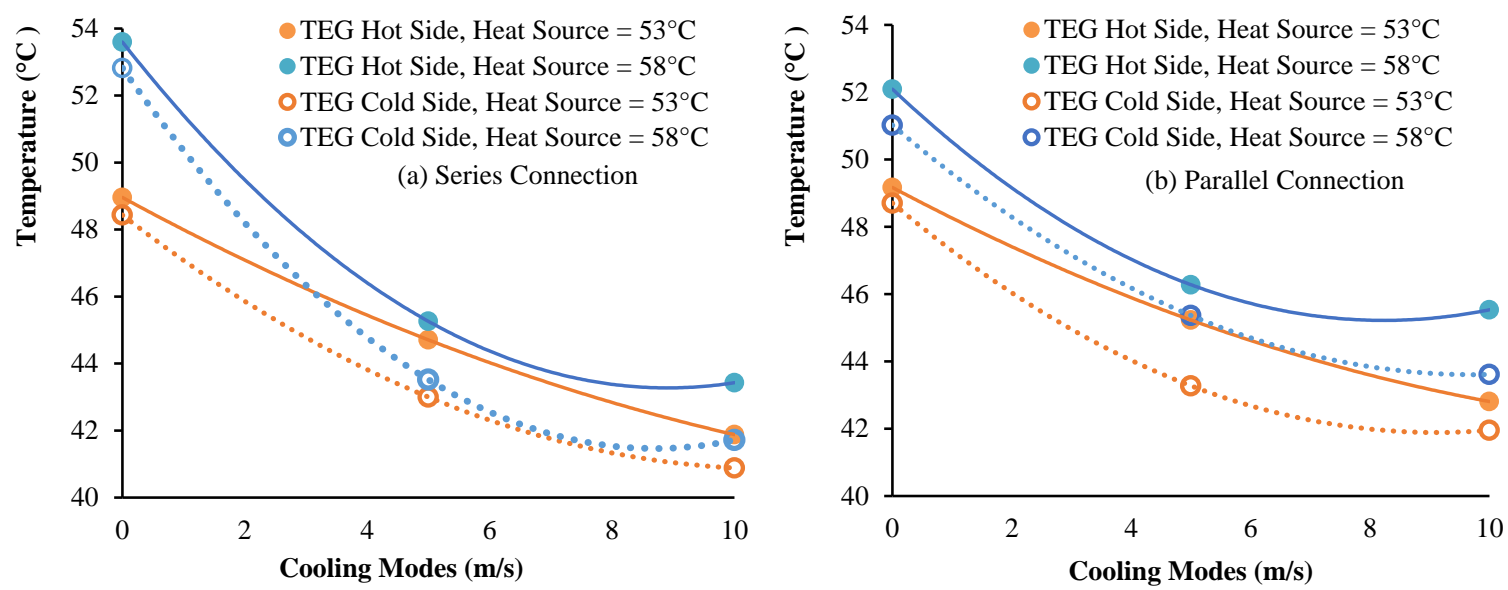

Figure 4: The hot and cold side temperatures under various cooling modes for (a) series connection and (b) parallel connection

The surface temperature profiles of the TEG cells are plotted in Fig. 4. Generally, the hot and cold sides of the TEG responded uniquely to the changes in hot stream temperature and cold stream velocity. The hot-side TEG temperature was approximately 4 to $6^{\circ} \mathrm{C}$ lower than the nominal hot air stream temperature, which was dependant to the convection mechanics of an impinging jet streamline on a vertical flat surface. Due to the 4-cell configuration, it was difficult to obtain a uniform surface heating compared to a single cell configuration as discussed by Mohamed et al. [25] for linear streamlines.

Under natural convection cooling, it was evident that there was very little TEG cooling through the heat sink and heat pipe as the surface temperatures were nearly identical. The introduction of moving cooling air streams at $5 \mathrm{~m} / \mathrm{s}$ and $10 \mathrm{~m} / \mathrm{s}$ led to a visible reduction of temperature at both sides of the TEG surfaces. The lowest surface temperature was demonstrated at $10 \mathrm{~m} / \mathrm{s}$ as greater mass of energized particles from TEG surface dissipated through the cooling system (heatpipes, fins) by conduction and convection kinetics. Thus, $5 \mathrm{~m} / \mathrm{s}$ generated the hottest TEG surface temperatures under active cooling system. The hot-side temperatures reduced in response to the effective cooling at the cold-side. The plotted steady-state temperatures indicated that the surface temperature differences were more visible at a higher hot stream temperature where the temperature difference tended to increase as the cooling air stream velocity increased. For the lower hot stream temperature, the temperature difference tended to reduce as the cooling air velocity increased. Theoretically, a higher TEG surface temperature would lead to a higher electrical generation. The obtained temperature difference was in the range of $0.46^{\circ} \mathrm{C}$ to $1.95^{\circ} \mathrm{C}$, which was logical for energy recovery from a low-grade waste stream. Since the TEG cell power generation is dependent on temperature difference, it is ideal for the cooling modes to only reduce the temperature on the cold side. However, the excitation of free electrons within the semiconductors are driven by the rate of heat flow; therefore, it should be noted that the performance of a TEG is a combination of asymptotic heat transfer mechanics at each component, most especially at the heated TEG surface.

Figs. 5 and 6 show that the TEG produced linear I-V and parabolic P-V profiles across all the WHT and cooling modes, which was consistent with the I-V and P-V profiles for TEG cells as reported in [25, 27]. When the resistance in the circuit varied, a reduction in current as the voltage of the TEG module increased was obtained which satisfied the Ohm's law. The TEG electrical potential towards WHT was directly proportional and increased as higher temperatures were supplied from the heat source. The improvement in short circuit current $\left(\mathrm{I}_{\mathrm{SC}}\right)$ as the WHT increased from 53 to $58^{\circ} \mathrm{C}$ was $20 \%$ for the natural convection cooling, $54 \%$ for forced convection at $5 \mathrm{~m} / \mathrm{s}$ and $35 \%$ for $10 \mathrm{~m} / \mathrm{s}$. The $5^{\circ} \mathrm{C}$ WHT change also improved the open circuit voltage (OCV) by $47 \%, 10 \%$ and $9 \%$ for the passive cooling, active cooling at $5 \mathrm{~m} / \mathrm{s}$ and $10 \mathrm{~m} / \mathrm{s}$, respectively.

The peaks of the parabolic P-V profiles were designated as the Maximum Power Point (MPP) of the TEG modules. The $5^{\circ} \mathrm{C}$ WHT change enhanced the MPP of each cooling mode by $61 \%, 67 \%$, and $54 \%$ for natural 
convection, forced convection at $5 \mathrm{~m} / \mathrm{s}$ and $10 \mathrm{~m} / \mathrm{s}$, respectively. The rise in MPP was due to the higher potential thermal energy that created a greater voltage potential across the cells for the electrons to flow. The highest MPP on both TEG circuit connections was at the conditions of active cooling mode of $10 \mathrm{~m} / \mathrm{s}$ and WHT of $58^{\circ} \mathrm{C}$ with $1940 \mu \mathrm{W}$ for series and $723 \mu \mathrm{W}$ for parallel. This led a MPP increment of $168 \%$ when the TEG module was connected in series compared to parallel connection. The parallel circuit allowed the TEG cells in the module to share the same output wire that was connected to the DC electric loader; thus, sharing the same voltage potential. In contrast, the series TEG connection had the accumulation of voltage potential on every TEG connection based on Kirchhoff voltage law where the sum of the voltages in a loop must be equal to zero.

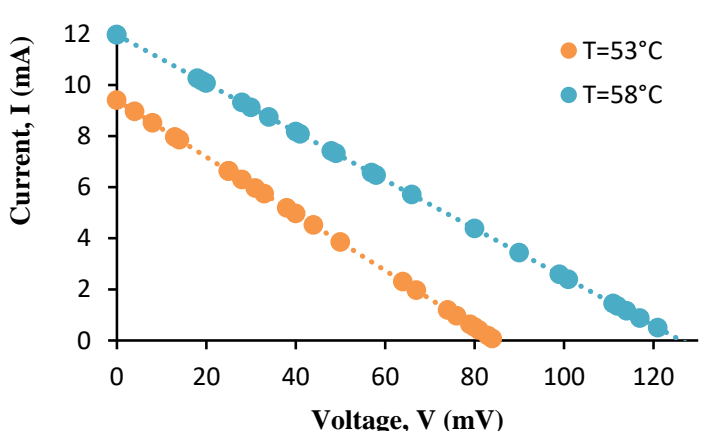

(a)

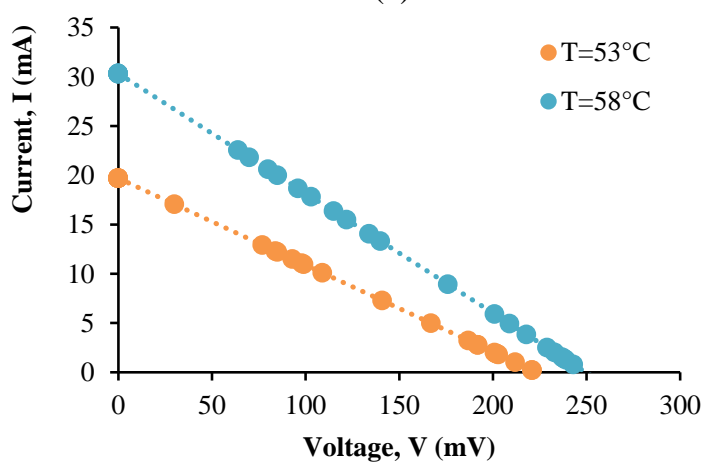

(c)

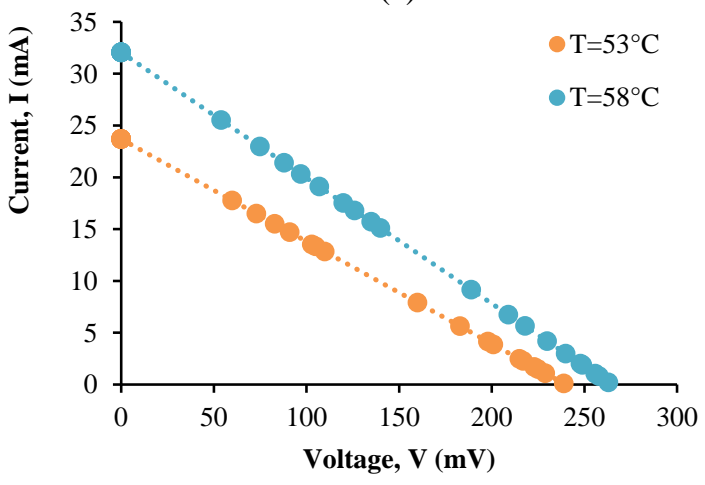

(e)

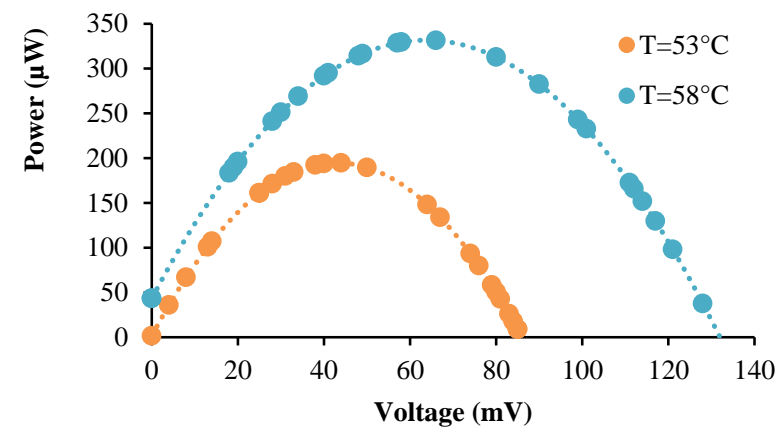

(b)

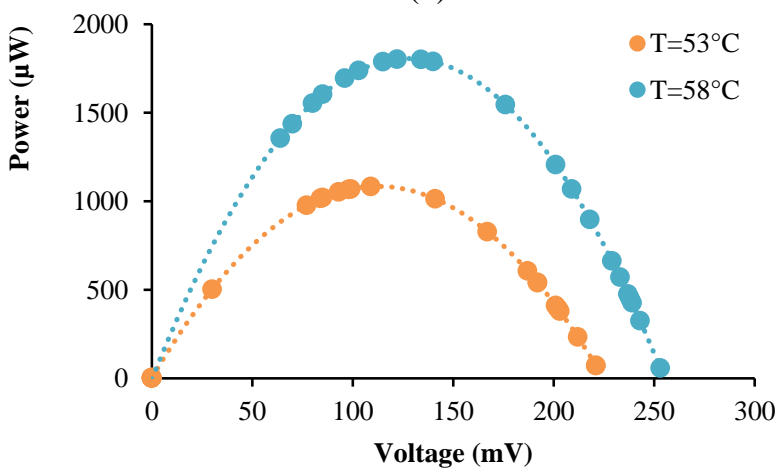

(d)

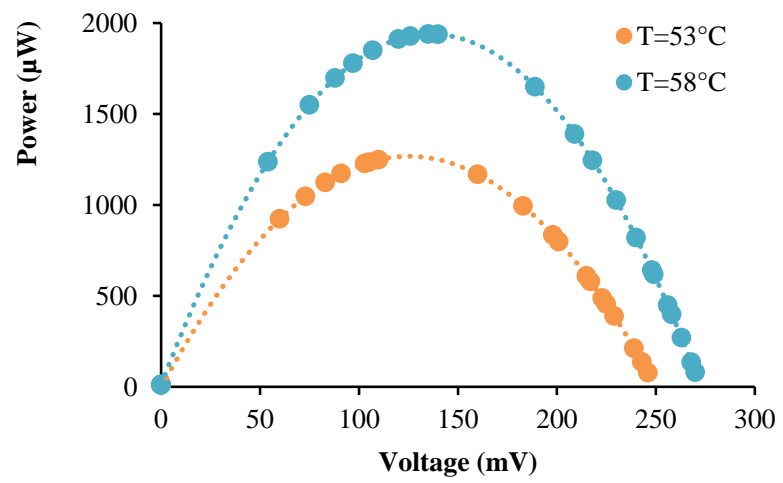

(f)

Figure 5: I-V and P-V profiles for the series circuit connection; (a) \& (b) Natural Convection, (c) \& (d) Forced Convection $(5 \mathrm{~m} / \mathrm{s}),(\mathrm{e}) \&$ (f) Forced Convection $(10 \mathrm{~m} / \mathrm{s})$ 


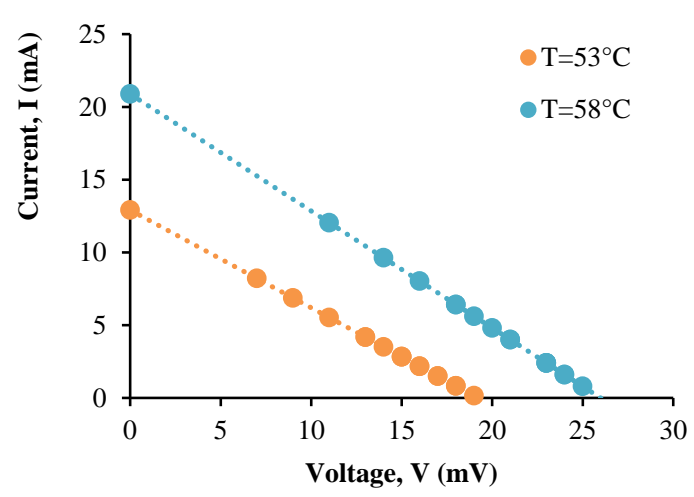

(a)

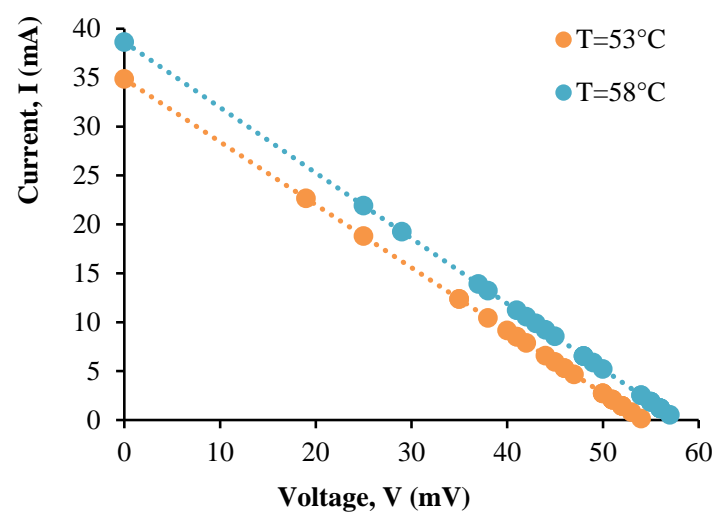

(c)

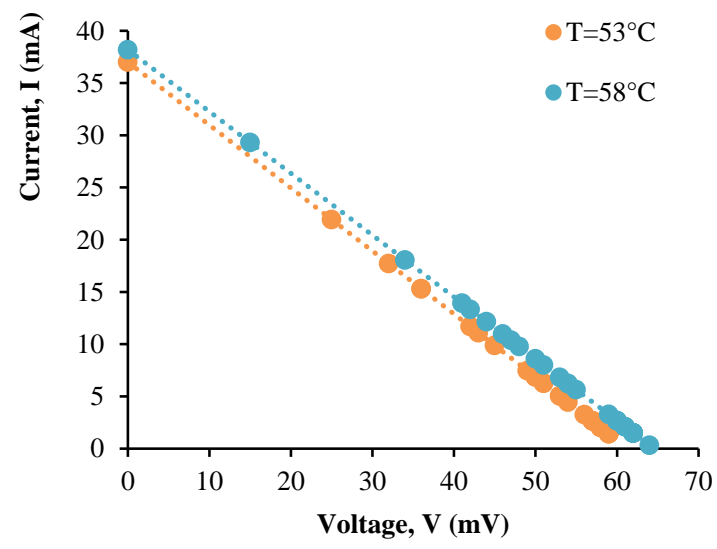

(e)

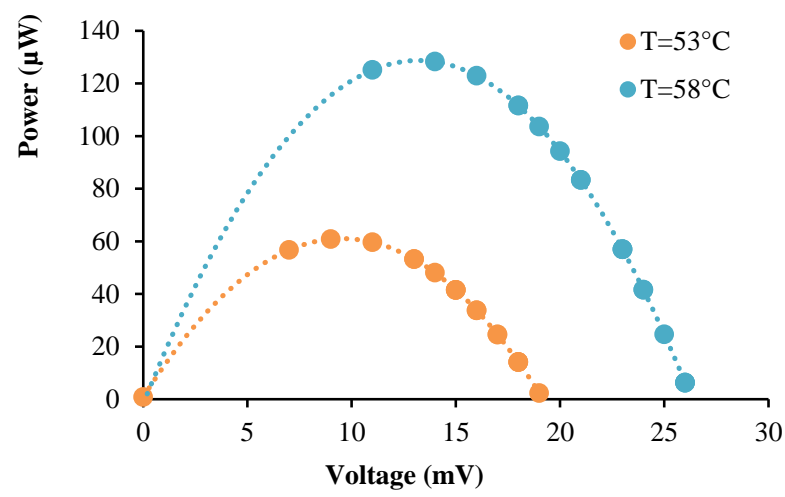

(b)

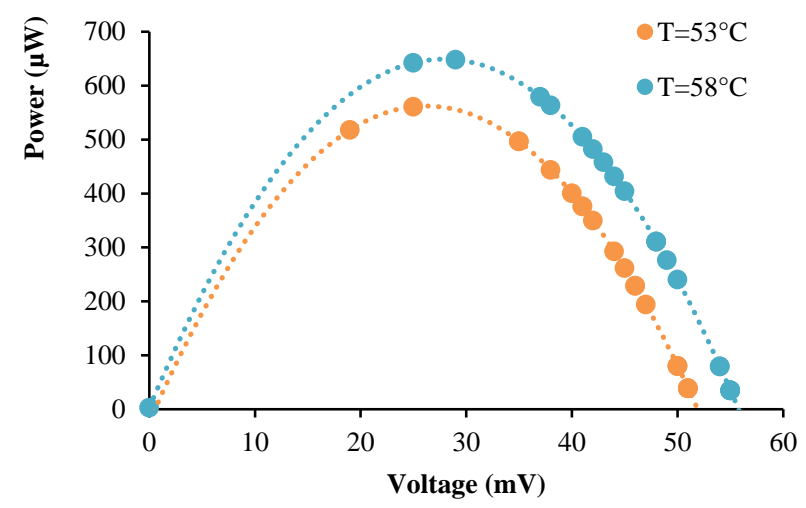

(d)

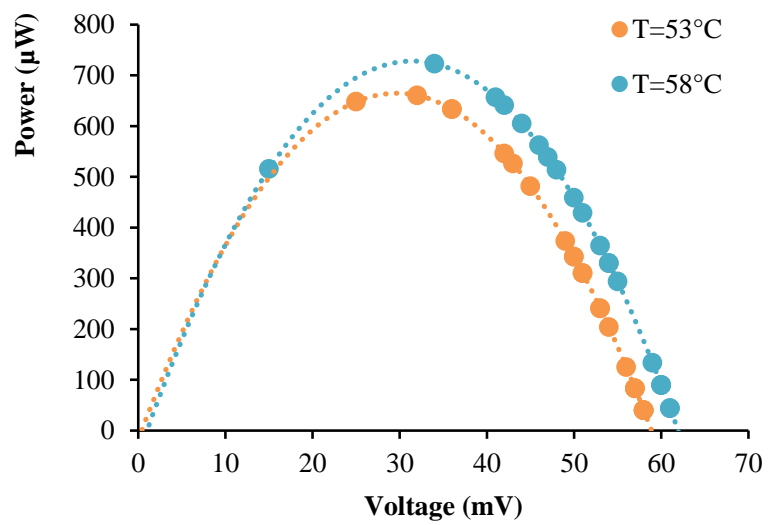

(f)

Figure 6: I-V and P-V profiles for the parallel circuit connection; (a) \& (b) Natural Convection, (c) \& (d) Forced Convection $(5 \mathrm{~m} / \mathrm{s})$, (e) \& (f) Forced Convection $(10 \mathrm{~m} / \mathrm{s})$

The active cooling modes have evidently improved the electrical power outputs compared to cooling under natural convection. Fig. 7 compares the MPP of the 4-cell TEG module for different WHT and cooling modes for series and parallel circuit connections. The series connection produced 2 to 2.5 times higher MPP than the parallel connection. The visible improvement of power conversion indicated potential exploration on multiple series HPTEG WHR system designed for a better absorption of waste heat and combined heat power generation. Despite the moderate power conversion, the parallel connection would be beneficial for a reversed system that required least power for thermal generations. Such reversed process of Seebeck effect was Peltier effect which consumed electrical energy in the production of heat transfer between the device's TEC (thermo electric cooler) surfaces. This configuration required minimum power for multiple TEC cooling or heating. The enhancement of achievable MPP from natural convection cooling to forced convection cooling is generally a factor between 5 and 10 . However, the increase of cooling air velocity from $5 \mathrm{~m} / \mathrm{s}$ to $10 \mathrm{~m} / \mathrm{s}$ merely enhanced the MPP by 4 to $14 \%$. This 
was lower than the reported enhancement for a single cell TEG under similar hot stream and cold stream temperatures and velocities as reported by Mohamed et al. [28]. The possible reason was due to the heat pipe configuration for the 4-cell assembly that did not effectively adapt to the changes in cooling potential at the heat sink. The bending of the heat pipes might have disrupted the effectiveness of the wick structure within the heat pipe, leading to disruption of the vapour flow from the evaporator to the condenser sections in the heat pipe. New heat pipe-TEG cell interface designs should be explored to allow rapid cell cooling responses from the dynamic motion of the FCV.

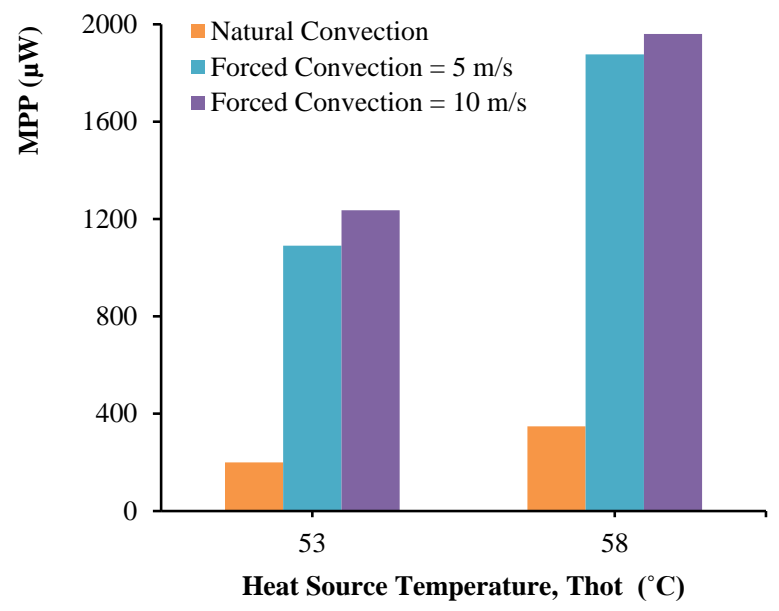

(a)

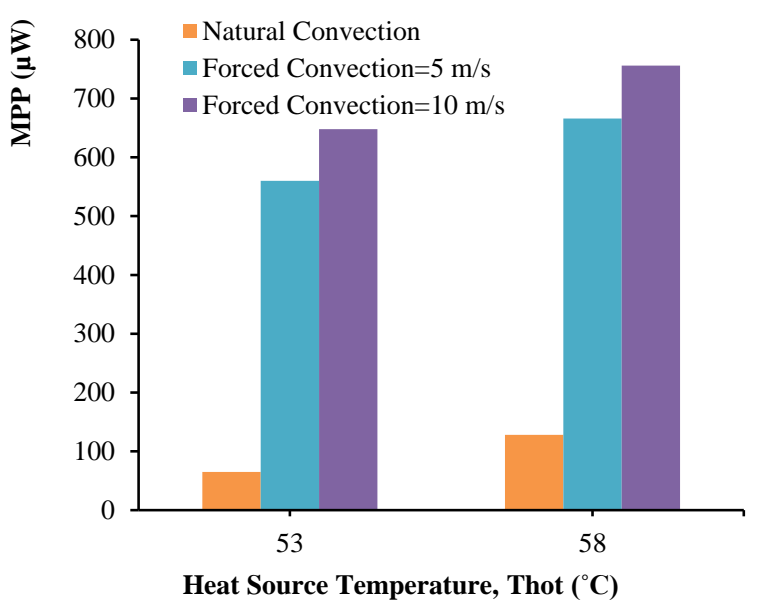

(b)

Figure 7: The Maximum Power Point under various heat source temperatures and cooling modes for a) series connection; b) parallel connection

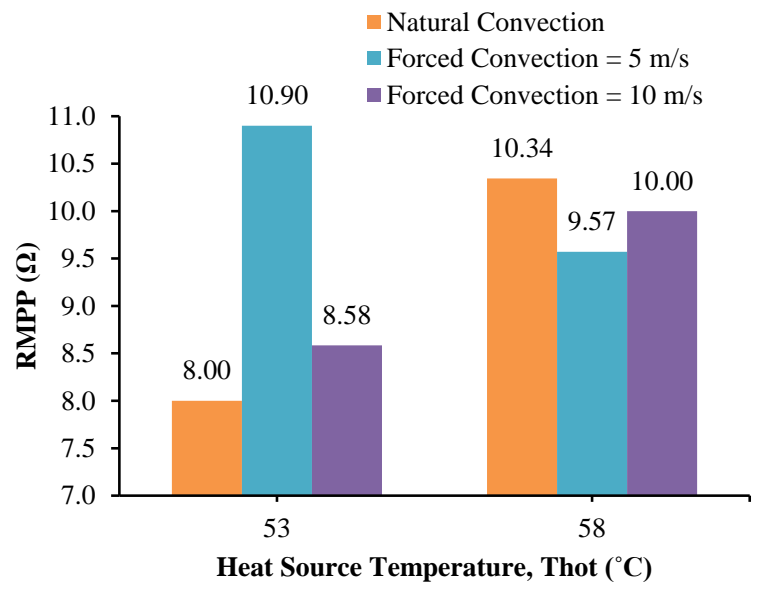

(a)

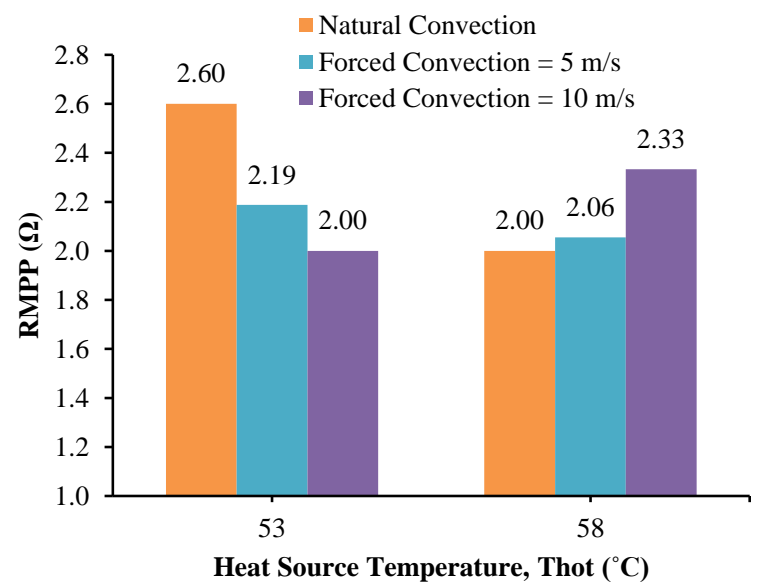

(b)

Figure 8: The Maximum Power Point Resistance under various heat source temperatures and cooling modes for a) series connection; b) parallel connection

Fig. 8 compares the circuit resistance at the MPP $\left(\mathrm{R}_{\mathrm{MPP}}\right)$ which was a condition obtained when the internal resistance of the TEG matched the load resistance that was adjusted via the DC electronic loader. By knowing and mapping the $\mathrm{R}_{\mathrm{MPP}}$ to specific operating conditions, the TEG circuit can be programmed to operate under dynamic resistance values that can continuously deliver maximum power at any heating and cooling conditions. In general, the calculated $\mathrm{R}_{\mathrm{MPP}}$ profiles are erratic for this preliminary study and an equation for the resistance

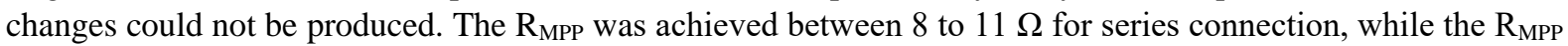
for parallel connection was significantly lower, between 2 to $2.6 \Omega$ for each heat source under various cooling modes. However, the small range of $\mathrm{R}_{\mathrm{MPP}}$ for each test setup showed the reliability of the TEG module design and cell quality to produce its peak performance at a constant and specific range of load resistance. It also pointed to 
the consistency of the experimental setup and operation. The obtained $\mathrm{R}_{\mathrm{MPP}}$ was already useful for a simple control algorithm of the TEG power regulator module under the specified operating conditions.

\subsection{Recommendation for design improvement}

Several modifications could be made to improve electrical power output. The heat sink design needs to be improved by optimizing the surface area for rapid TEG cooling even at low speeds. The number of heat pipes for the 4-cell module should also be studied in detail by including the most effective interfacing with the cold-side of the TEG cells. A passive system to channel the waste heat stream uniformly towards the cell surfaces is also a system improvement that could lead to greater electrical outputs.

\subsection{CONCLUSION}

A WHR system based on a $1 \mathrm{~kW}$ PEM fuel cell using a 4-cell TEG module was developed and the electrical output profiles was experimentally assessed under variations of hot stream temperature, cooling air velocity and electrical circuit connections. A maximum power of $1940 \mu \mathrm{W}$ was produced from the series connection at $58^{\circ} \mathrm{C}$ WHT and $10 \mathrm{~m} / \mathrm{s}$ cooling air velocity, with a corresponding external resistance of $10 \Omega$ and voltage of $140 \mathrm{mV}$. Other important observations from this work are:

i. The TEG maximum power output was highly affected by the mode and intensity of cooling at the heat sinks. Forced convection significantly magnified the power output due to higher heat transfer rates across the heatsink, heat pipes and copper plate on the cold-side of the module.

ii. The series circuit connection produced at least double the MPP than the parallel circuit connection due to the accumulation of TEG cells potential.

iii. The main motivation of FCV WHR systems is the amount of power recovered as it is more beneficial to embed a series of TEG configuration in these systems.

iv. The optimal circuit resistances for the TEG module to achieve MPP were 8 to $11 \Omega$ for the series and 2 to $2.2 \Omega$ for parallel connection.

\section{ACKNOWLEDGEMENT}

The authors would like to thank Universiti Teknologi MARA (UiTM) for the facilities and the Ministry of Higher Education Malaysia for the financial support given under 600-RMI/FRGS 5/3 (150/2014).

\section{REFERENCES}

[1] M. Z. Jacobson, "Cleaning the Air and Improving Health with Hydrogen Fuel-Cell Vehicles," Science, vol. 308, no. 5730, pp. 1901-1905, 2005, doi: 10.1126/science.1109157.

[2] J. Shin, W.-S. Hwang, and H. Choi, "Can hydrogen fuel vehicles be a sustainable alternative on vehicle market?: Comparison of electric and hydrogen fuel cell vehicles," Technol. Forecast. Soc. Change, vol. 143, pp. 239-248, 2019, doi: 10.1016/j.techfore.2019.02.001.

[3] "Fuel Cell Systems," Office of Energy, Energy Efficiency \& Renewable. https://www.energy.gov/eere/fuelcells/fuel-cell-systems.

[4] Z. Hbilate, S. Hamham, Y. Naimi, and D. Takky, "Study and Analysis of the Thermal Impact on the Overall Performance of the Proton Exchange Membrane Fuel Cell and Its Management and the Exploitation of PEM Fuel Cells in a Cogeneration System: Review," Proceedings of the 1st International Conference of Computer Science and Renewable Energies. SCITEPRESS - Science and Technology Publications, 2018, doi: 10.5220/0009772501150124.

[5] S. G. Kandlikar and Z. Lu, "Thermal management issues in a PEMFC stack - A brief review of current status," Appl. Therm. Eng., vol. 29, no. 7, pp. 1276-1280, 2009, doi: 10.1016/j.applthermaleng.2008.05.009.

[6] A. Faghri and Z. Guo, "Challenges and opportunities of thermal management issues related to fuel cell technology and modeling," Int. J. Heat Mass Transf., vol. 48, no. 19-20, pp. 3891-3920, 2005, doi: 10.1016/j.ijheatmasstransfer.2005.04.014.

[7] H. Jouhara, N. Khordehgah, S. Almahmoud, B. Delpech, A. Chauhan, and S. A. Tassou, "Waste heat recovery technologies and applications," Therm. Sci. Eng. Prog., vol. 6, pp. 268-289, 2018, doi: 10.1016/j.tsep.2018.04.017.

[8] M. Fairuz M. R., W. A. Najmi W. M. and Rahim A., "Cooling Mechanisms and Contribution Analysis of an Experimental Polymer Electrolyte Membrane Fuel Cell System," 3rd Eng. Conf. Adv. Mech. Manuf. Sustain. Environ., May 2014, pp. 1-4, 2010.

[9] W. A. N. W. Mohamed and R. Atan, "Experimental thermal analysis on air cooling for closed-cathode Polymer Electrolyte Membrane fuel cells," Int. J. Hydrogen Energy, vol. 40, no. 33, pp. 10605-10626, Sep. 2015, doi: 10.1016/J.IJHYDENE.2015.06.095. 
[10] D. Rowe, “Thermoelectric waste heat recovery as a renewable energy source," Int. J. Innov. Energy Syst. Power, vol. 1, Jan. 2006.

[11] M. Ebrahimi and E. Derakhshan, "Design and evaluation of a micro combined cooling, heating, and power system based on polymer exchange membrane fuel cell and thermoelectric cooler," Energy Convers. Manag., vol. 171, pp. 507-517, Sep. 2018.

[12] W. He, S. Wang, and Y. Yang, "Peak power evaluation and optimal dimension design of exhaust heat exchanger for different gas parameters in automobile thermoelectric generator," Energy Convers. Manag., vol. 151, pp. 661-669, Nov. 2017.

[13] C. Babu and P. Ponnambalam, "The role of thermoelectric generators in the hybrid PV/T systems: A review," Energy Convers. Manag., vol. 151, pp. 368-385, Nov. 2017.

[14] X. Guo et al., "Performance assessment of a combined system consisting of a high-temperature polymer electrolyte membrane fuel cell and a thermoelectric generator," Energy, vol. 179, pp. 762-770, 2019, doi: 10.1016/j.energy.2019.05.030.

[15] A. Makki, S. Omer, Y. Su, and H. Sabir, "Numerical investigation of heat pipe-based photovoltaicthermoelectric generator (HP-PV/TEG) hybrid system," Energy Convers. Manag., vol. 112, pp. 274-287, Mar. 2016.

[16] M. F. Remeli et al., "Experimental investigation of combined heat recovery and power generation using a heat pipe assisted thermoelectric generator system," Energy Convers. Manag., vol. 111, pp. 147-157, 2016, doi: 10.1016/j.enconman.2015.12.032.

[17] M. Hasani and N. Rahbar, "Application of thermoelectric cooler as a power generator in waste heat recovery from a PEM fuel cell - An experimental study," Int. J. Hydrogen Energy, vol. 40, no. 43, pp. 15040-15051, Nov. 2015.

[18] X. Gao, S. J. Andreasen, M. Chen, and S. K. Kær, "Numerical model of a thermoelectric generator with compact plate-fin heat exchanger for high temperature PEM fuel cell exhaust heat recovery," Int. J. Hydrogen Energy, vol. 37, no. 10, pp. 8490-8498, May 2012, doi: 10.1016/J.IJHYDENE.2012.03.009.

[19] X. Gao, M. Chen, S. J. Andreasen, and S. K. Kær, "Potential usage of thermoelectric devices in a hightemperature polymer electrolyte membrane (PEM) fuel cell system: Two case studies," J. Electron. Mater., vol. 41, no. 6, pp. 1838-1844, Jun. 2012, doi: 10.1007/S11664-012-2098-2.

[20] X. Gao, S. J. Andreasen, S. K. Kær, and L. A. Rosendahl, "Optimization of a thermoelectric generator subsystem for high temperature PEM fuel cell exhaust heat recovery," Int. J. Hydrogen Energy, vol. 39, no. 12, pp. 6637-6645, Apr. 2014.

[21] W. H. Chen, C. Y. Liao, C. I. Hung, and W. L. Huang, "Experimental study on thermoelectric modules for power generation at various operating conditions," Energy, vol. 45, no. 1, pp. 874-881, 2012, doi: 10.1016/j.energy.2012.06.076.

[22] W. H. Chen, Y. X. Lin, Y. Bin Chiou, Y. L. Lin, and X. D. Wang, "A computational fluid dynamics (CFD) approach of thermoelectric generator (TEG) for power generation," Appl. Therm. Eng., vol. 173, Jun. 2020, doi: 10.1016/J.APPLTHERMALENG.2020.115203.

[23] S. Khanmohammadi, M. Rahmani, F. Musharavati, S. Khanmohammadi, and Q.-V. Bach, "Thermal modeling and triple objective optimization of a new compressed air energy storage system integrated with Rankine cycle, PEM fuel cell, and thermoelectric unit," Sustain. Energy Technol. Assessments, vol. 43, p. 100810, 2021, doi: 10.1016/j.seta.2020.100810.

[24] R. J. Parise and G. F. Jones, "Fuel cell thermal management with thermoelectric coolers," IECEC '02. 2002 37th Intersociety Energy Conversion Engineering Conference, 2002. IEEE, doi: 10.1109/iecec.2002.1392115.

[25] M. S. Sulaiman, B. Singh, and W. A. N. W. Mohamed, "Experimental and theoretical study of thermoelectric generator waste heat recovery model for an ultra-low temperature PEM fuel cell powered vehicle," Energy, vol. 179, pp. 628-646 2019. doi: 10.1016/j.energy.2019.05.022.

[26] M. S. Sulaiman, W. A. N. W. Mohamed, B. Singh, and M. F. Ghazali, "Validation of a Waste Heat Recovery Model for a 1kW PEM Fuel Cell using Thermoelectric Generator," IOP Conf. Ser. Mater. Sci. Eng., vol. 226, no. 1, Aug. 2017, doi: 10.1088/1757-899X/226/1/012148.

[27] B. Singh, W. A. N. W. Mohamed, M. N. F. Hamani, and K. Z. N. A. So, "Enhancement of low grade waste heat recovery from a fuel cell using a thermoelectric generator module with swirl flows," Energy, vol. 236, 2021, doi: 10.1016/j.energy.2021.121521.

[28] W. A. N. W. Mohamed, B. Singh, M. F. Mohamed, A. M. Aizuwan, and A. B. M. Zubair, "Effects of fuel cell vehicle waste heat temperatures and cruising speeds on the outputs of a thermoelectric generator energy recovery module," Int. J. Hydrogen Energy, vol. 46, no. 50, pp. 25634-25649, 2021. doi: 10.1016/j.ijhydene.2021.05.084. 